\title{
Urban Tree Selection for Diversity ${ }^{1}$
}

\author{
Deborah R. Hilbert, Andrew K. Koeser, and Robert J. Northrop²
}

\section{Introduction}

Urban tree diversity is important when attempting to create a healthy, beneficial, and resilient urban forest. Having a variety of trees can increase the aesthetic value for residents (Kiester 1996/1997) and create habitats for plants and animals (Tews et al. 2004). Some common street trees currently in the landscape are not site-appropriate and create infrastructure damage. By planting different types of trees in these locations, maintenance costs and infrastructure damage can be reduced and tree longevity increased. Perhaps most important, biodiverse forests are less vulnerable to the many pressures that affect them, such as pests, diseases, and climate change (Raupp et al. 2006; Lacan and McBride 2008; Roloff et al. 2009). The risks of having monocultures (i.e., large plantings of the same species or even cultivar) within the urban forest have played out historically as outbreaks of the chestnut blight fungus (Cryphonectria parasitica), Dutch elm disease (Ophiostoma ulmi), and more recently, emerald ash borer (Agrilus planipennis). These outbreaks left death and canopy voids across much of their host trees' planted range (Roane et al. 1986; Sinclair and Campana 1978; Raupp et al. 2006). In Florida, urban foresters are concerned with the spread of lethal bronzing (formerly Texas Phoenix Palm Decline), a fatal disease caused by a phytoplasma that affects palms in the genus Phoenix as well as other common palm species, like our native cabbage palm (Sabal palmetto) (Bahder and Helmick 2019).
While urban landscapes are capable of supporting high levels of plant diversity (Alvey 2006), more can be done to encourage and conserve biodiversity in the urban forest. For example, in Tampa, Florida, just ten species make up $63 \%$ of the city's inland urban forest (Landry et al. 2018), and a similar pattern can be found in other Florida municipalities. The limited diversity of trees in cities stems, in part, from the overreliance on a few sturdy tree species that can survive urban growing conditions. Urban environments are tough on trees, with frequently hotter temperatures than regional averages (Stewart and Oak 2012), more alkaline and compacted soils (Urban 2008), and limited rooting space. Often people select and plant the same few hardy species like crepe myrtle, Lagerstroemia indica, and live oak, Quercus virginiana. In turn, producers focus on growing such popular, successful species. This encourages a feedback loop in which a limited variety of trees are grown, purchased, and planted.

Choosing underused trees to plant has to be strategic. Mainly, the species must be suitable to the planting location (Richards 1982/1983). Researchers have developed tree databases (Vogt et al. 2017) and scoring matrices based on urban conditions, climate (Roloff et al. 2009), and pest vulnerability (Lacan and McBride 2008) to aid in tree selection. Future climate predictions are especially important to consider when working with organisms as long-lived as trees. For example, climate predictions for central Florida include overall hotter temperatures, more severe storms, disrupted rainy season patterns, and

1. This document is ENH1325, one of a series of the Environmental Horticulture Department, UF/IFAS Extension. Original publication date September 2020. Visit the EDIS website at https://edis.ifas.ufl.edu for the currently supported version of this publication.

2. Deborah R. Hilbert, biological scientist; Andrew K. Koeser, assistant professor, Environmental Horticulture Department, CLCE, UF/IFAS Gulf Coast Research and Education Center; and Robert J. Northrop, program county Extension agent IV, forestry, UF/IFAS Extension Hillsborough County; UF/IFAS Extension Gainesville, FL 32611.

The Institute of Food and Agricultural Sciences (IFAS) is an Equal Opportunity Institution authorized to provide research, educational information and other services

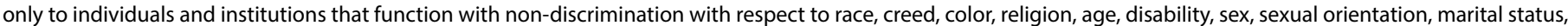

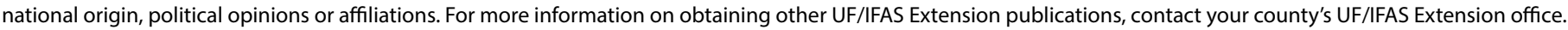
U.S. Department of Agriculture, UF/IFAS Extension Service, University of Florida, IFAS, Florida A \& M University Cooperative Extension Program, and Boards of County Commissioners Cooperating. Nick T. Place, dean for UF/IFAS Extension. 
sea-level rise (IPCC 2013; Florida Oceans and Coastal Council 2010; Balaguru et al. 2016). Keeping this in mind, researchers at the University of Florida have partnered with the Central Florida Urban Forest Diversity Working Group and partners from Pinellas County, Hillsborough County, the City of Lakeland, and the City of Orlando to investigate the use of underutilized tree species in central Florida. The methods used to select the trees for this trial can be followed by others who are choosing new trees to plant.

\section{Underutilized-Tree Selection}

\section{Process}

In attempting to increase urban forest biodiversity, we suggest the following steps:

\section{Assemble a local "tree matrix."}

We encourage practitioners to create a document that lists trees that are suitable to their specific region and its unique physical and climatic conditions. The document could outline each tree's typical characteristics and site requirements (e.g., mature height, flood tolerance, distance from paved surface). This chart can be used to begin to identify potential species that are underutilized as well as potential planting sites. A local example of a tree matrix is available through the City of Tampa (https://www.tampatreemap.usf.edu/tree-matrix).

\section{Identify underutilized tree species.}

We defined "underutilized" to be trees that made up less than $1 \%$ of the total tree population by stem count, using local inventory data from 7 municipalities.

\section{Examine future climate predictions.}

Trees are typically long-lived organisms, and we want the trees we plant to be able to survive decades into the future. As such, it is important to consider future climate trends (Brandt et al. 2016). Predicted climate trends in our area include an increase in days with temperatures over $26.7^{\circ} \mathrm{C}\left(80^{\circ} \mathrm{F}\right)$, decrease in wet-season precipitation, and more extreme tropical storms (Florida Oceans and Coastal Council 2010).

4. Develop criteria to narrow the list.

Underutilized trees can be defined as species that have the potential to thrive in an area, yet make up less than $1 \%$ of the canopy (by tree count). A list of such species can be readily obtained in cities or properties that have a tree inventory (a database of the trees planted). Some additional criteria to consider are:

- Native vs. non-native-There are many reasons to choose native species, but non-native, noninvasive species have shown to be successful in urban areas, which can be quite different from their predevelopment state.

- No invasive potential-When selecting non-native species, take care to ensure the trees are not on the UF/ IFAS Assessment invasive species list (https://plants. ifas.ufl.edu/).

- No known history of failure in the local area-Talking to local practitioners will help determine which trees are known to perform better or worse in different areas. Alternatively, look for underutilized species that are present as mature, healthy individuals in your area.

- Low risk of contracting common diseases and pestsWhen selecting species, refer to the Florida Forest Service Forest Heath (https://www.freshfromflorida. com/Divisions-Offices/Florida-Forest-Service/OurForests/Forest-Health) and the UF/IFAS Forest Health Extension (http://sfrc.ufl.edu/extension/forest_health/) websites.

- No susceptibility to site-specific conditions-Within a given city or property, planting sites can vary significantly with regard to light availability, drainage, soils, and other factors that influence tree health. A number of resources that compile the cultural needs of individual species are available.

- Note plant traits that are ill-suited for the trees' intended use-Characteristics like showy fruits may add seasonal attractiveness and foster native birds and wildlife.

However, these same fruits are considered a nuisance if trees are to be planted near sidewalks in public spaces. Plant selection guides can help identify species with traits that are both desired and disliked.

5. Assemble a list of potential trees and vet them with the community/others.

Members of the Central Florida Urban Forest Diversity Working Group collaborated to create a list of 35 species that they considered underused, but good choices for the region. Others seeking to select trees might consult experts such as Extension agents and certified arborists for ideas on potential trees, as well as people living in areas where planting could occur. 
6. Examine typical urban growing conditions.

Understanding the conditions of the location where new trees will be planted is always an important step. Besides knowing the amount of growing space, there are other considerations. For example, urban environments often have disrupted hydrological cycles due to the large amount of impermeable surfaces (e.g., sidewalks, roads, parking lots). This means trees are often exposed to both drought and flood conditions. Urban environments also experience the urban heat-island effect, and the soils may have high soil $\mathrm{pH}$ and salinity values. In Florida, high winds are common during tropical storms.

7. Search for species availability.

Once a final list of site-appropriate species has been constructed, sources for the selected trees need to be identified. Published nursery directories and online databases like PlantAnt can help with this process. For harder-to-source species, flexibility in accepting smallersize nursery material may be necessary. Alternatively, the findings from the above steps may serve as the basis and justification of more formalized contract growing agreements. When purchasing plants, it is important to be mindful of the following:

- Budget-scarcity of a species in the desired size/grade will increase the price.

- Tree size-often, underutilized trees species that lack an established market may not be available in large sizes (because this represents a greater investment by/risk to the grower).

- Tree quantity — some species may be found at only a few (or a single) nursery, making it harder to plant large numbers of an underutilized tree species for larger city- or countywide planting programs.

- Tree quality-similar to the limitations on plant size, there may be limitations regarding the quality of plants available if only produced by a few growers. While minor issues can be corrected with post-planting care and structural pruning, not every tree is salvageable.

\section{Conclusion}

The steps outlined above can be used as guiding points as you begin to consider using less common trees to diversify the urban forest. Undoubtedly, you may find availability from growers to be a limiting factor. By discussing the use of underutilized trees with growers, homeowners, urban foresters, etc., more interest will be spurred. Increasing tree species diversity is an undertaking that will need to be addressed on all ends of the planting process, from consumer demand to production. Additionally, it is important to conduct more studies like the central Florida planting trial in order to highlight less common trees and understand which trees do best in different sites.

\section{References}

Alvey, A. A. 2006. "Promoting and Preserving Biodiversity in the Urban Forest." Urban Forestry \& Urban Greening 5 (4): 195-201. https://doi.org/10.1016/j.ufug.2006.09.003

Bahder, B. W., and E. E. Helmick. 2019. Lethal Bronzing Disease (LBD). PP243. Gainesville: University of Florida Institute of Food and Agricultural Sciences. https://edis.ifas. ufl.edu/pp163

Balaguru, K., D. R. Judi, and L. R. Leung. 2016. "Future Hurricane Storm Surge Risk for the U.S. Gulf and Florida Coasts Based on Projections of Thermodynamic Potential Intensity." Climatic Change 138:99-110. https://doi. org/10.1007/s10584-016-1728-8

Brandt, L., A. Lewis, R. Fahey, L. Scott, L. Darling, and C. Swanston. 2016. "A Framework for Adapting Urban Forests to Climate Change." Environ. Sci. Policy 66:393-402. https:// doi.org/10.1016/j.envsci.2016.06.005

Florida Oceans and Coastal Council. 2010. Climate Change and Sea-Level Rise in Florida: An Update of "The Effects of Climate Change on Florida's Ocean and Coastal Resources." [2009 Report] Tallahassee, Florida. vi + 26 pp.

IPCC. 2013. Climate Change 2013: The Physical Science Basis. Contribution of Working Group I to the Fifth Assessment Report of the Intergovernmental Panel on Climate Change. Edited by T. F. Stocker, D. Qin, G.-K. Plattner, M. Tignor, S. K. Allen, J. Boschung, A. Nauels, Y. Xia, V. Bex and P. M. Midgley. Cambridge, United Kingdom, and New York, NY: Cambridge University Press. 1535 pp.

Kiester, A. R. 1997. "Aesthetics of Biological Diversity." Human Ecology Review 3 (2): 151-157.

Laçan, I., and J. McBride. 2008. "Pest Vulnerability Matrix (PVM): A Graphic Model for Assessing the Interaction between Tree Species Diversity and Urban Forest Susceptibility to Insects and Diseases." Urban For. Urban Green. 7 (4): 291-300. https://doi.org/10.1016/j.ufug.2008.06.002 
Landry, S., A. Koeser, R. Northrop, D. McLean, G. Donovan, M. Andreu, and D. Hilbert. 2018. City of Tampa Tree Canopy and Urban Forest Analysis 2016. Tampa: City of Tampa, Florida.

Raupp, M., A. Cumming, and E. Raupp. 2006. "Street Tree Diversity in Eastern North America and Its Potential for Tree Loss to Exotic Borers." Arboricult. Urban For. 32 (6): 297-304.

Richards, N. A. 1982/1983. "Diversity and Stability in a Street Tree Population." Urban Ecology 7:159-171. https:// doi.org/10.1016/0304-4009(83)90034-7

Roane, M. K., G. J. Griffin, and J. R. Elkins. 1986. Chestnut Blight, Other Endothia Diseases, and the Genus Endothia. St. Paul, MN: APS Press.

Roloff, A., S. Korn, and S. Gillner. 2009. “The ClimateSpecies-Matrix to Select Tree Species for Urban Habitats Considering Climate Change." Urban For. Urban Green. 8 (4): 295-308. https://doi.org/10.1016/j.ufug.2009.08.002

Sinclair, W. A., and R. J. Campana. 1978. "Dutch Elm Disease: Perspectives after 60 Years." Northeast Regional Research Publication 8(5). 52 pp.

Stewart, I. D., and T. R. Oak. 2012. "Local Climate Zones for Urban Temperature Studies." Bulletin of the American Meteorological Society 93 (12): 1879-1900. https://doi. org/10.1175/BAMS-D-11-00019.1

Tews, J., U. Brose, V. Grimm, K. Tielbörger, M. C. Wichmann, M. Schwager, and F. Jeltsch. 2003. "Animal Species Diversity Driven by Habitat Heterogeneity/Diversity: The Importance of Keystone Structures." Journal Biogeography 31 (1): 79-92. https://doi. org/10.1046/j.0305-0270.2003.00994.x

Urban, J. 2008. Up by Roots: Healthy Soils and Trees in the Built Environment. Champaign, IL: International Society of Arboriculture (ISA).

Vogt, J., S. Gillner, M. Hofman, A. Tharang, S. Dettmann, T. Gerstenberg, C. Schmidt, H. Gebaruer, K. Van de Riet, U. Berger, and A. Roloff. 2017. "Citree: A Database Supporting Tree Selection for Urban Areas in Temperate Climate." Landscape and Urban Planning 157 (2017): 14-25. https:// doi.org/10.1016/j.landurbplan.2016.06.005 